\title{
Development of a Corporate-Based Beef Cattle Breeding Area
}

\author{
Hamdi Mayulu ${ }^{1}$, Irsan Tricahyadinata ${ }^{2^{*}}$ and Agus Soepriyadi ${ }^{3}$ \\ 1 Animal Sciences Department of Agricultural Faculty, Mulawarman University; hamdimayulu75@gmail.com \\ 2 Mulawarman University; irsan.tricahyadinata@feb.unmul.ac.id \\ 3 Mulawarman University; soepriyadi_agus@yahoo.com \\ * Correspondence: hamdimayulu75@gmail.com
}

\begin{abstract}
Livestock is an integral part of agriculture which significantly contributes to the economic and socio-economic development. Based on its potential in natural resources and human resources, East Kalimantan Province has opportunity to become a beef cattle development area. The development of a corporate-based beef cattle breeding area is an approach which taken toward industrial and business-oriented beef cattle breeding. The concept of breeder corporation will create new strengths such as strengths in human resources, capital, and banking in business development, which can more open the opportunities for the success and growth of the breeder's business. The development of a corporate-based beef cattle breeding area provides opportunities, including: 1) improving the competitiveness and added value of the region and beef cattle commodities in order to support national sustainable food security; 2) strengthening the livestock business system in one area management in a holistic manner; and 3) strengthening breeders institutions in accessing information, technology, public facilities and infrastructure, capital, processing and marketing, so that the concept is expected to be applied in East Kalimantan Province.
\end{abstract}

Keywords: Development; area; livestock; beef cattle; corporation

\section{Introduction}

Gaps and equity guarantee in the regional development as well as the food security is the issue in the national development (Bappenas, 2021), thus the policies should be a development acceleration-oriented based on the development of natural resources, human resources and integrated infrastructure (Secretariat General of Agriculture, 2018). The development of agriculture area is an effort conducted by government to accelerate the food self-sufficiency. The government attention on agriculture is closely related with livestock sub-sector, thus the development of livestock is always associated with the reorientation of agricultural development policy (Elly et al., 2018). The development of agricultural area by improving the breeders' economic institution become the direction of sustainable agricultural development. The principal of sustainable development is management and utilization of agricultural ecosystem by preserving the natural diversity, productivity, regeneration capacity, vitality and function so that they can fulfill present and future functions in accordance with ecological, economic and social functions at the local and national level as well as globally and does not harm other ecosystems (Cammarata et al., 2021). 
Livestock is an integral part of agriculture that makes a significant contribution to the economy and socio-economic development (Hegde, 2019). Livestock revitalization should be more emphasized on efforts to achieve self-sufficiency, food security, welfare and business sustainability (Mayulu and Daru, 2019). The livestock sub-sector is a commercial activity with a fairly high capital investment, and is an important source of livelihood for small farmers in developing countries (Hegde, 2019). Livestock has a very important and relevant role both from the health aspect (fulfillment for animal protein), the economic aspect (contributor to gross domestic product; investment) and social aspect (livelihood and employment) (Congio et al., 2021). Food availability, accessibility, and safety of animal-protein food sources are very important in supporting the health and welfare of the community and are prerequisites for food security (Traore et al., 2018). The gross domestic product (GDP) from livestock sub-sector in the 2016-2020 period showed an increase (4,00\% per year), namely: from IDR143.036,5 billion in 2016 increased to IDR167.084,8 billion in 2020. The level of investment in the livestock sub-sector in the 2015-2019 period experienced positive growth, namely: from IDR326,4 to IDR1.500,2 billion and domestic investment consistently increased year to year by $37.10 \%$ and the value of foreign investment also increased by $24,04 \%$ (Ditjen PKH, 2020).

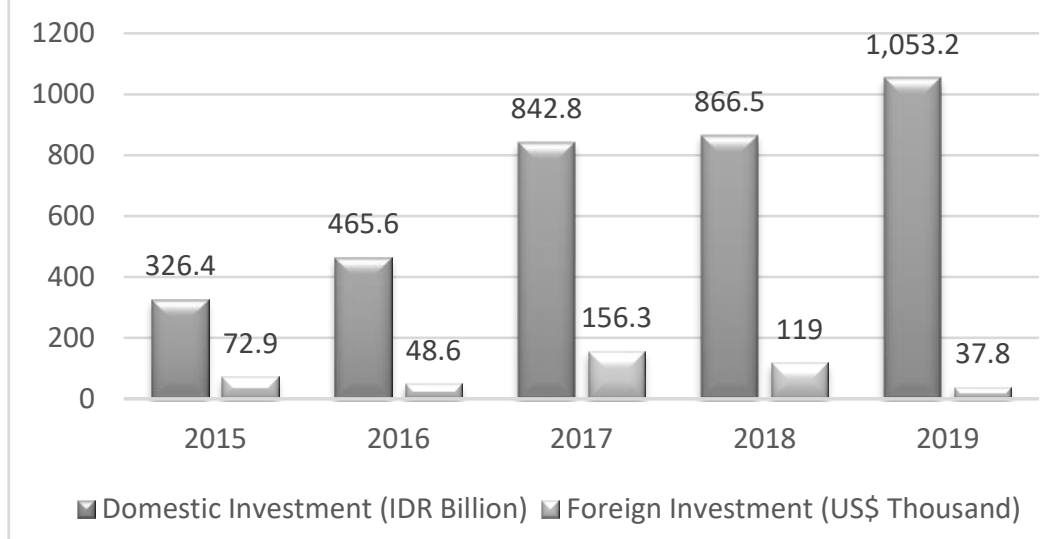

Figure 1. Investment in Livestock Sub-Sector Year 2015-2019 (Ditjen PKH, 2020).

The absorption of labor in the livestock sub-sector for the period 2014-2018 increased by $4.18 \%$ per year with the number of workers in 2018 reaching to 4.831 .211 people (Ditjen $\mathrm{PKH}, 2020)$. This increasing trend indicates the importance of livestock sub-sector in the social aspect (NABARD, 2018). This illustration below shows the meat consumption for the Indonesian population in 2017-2020. 


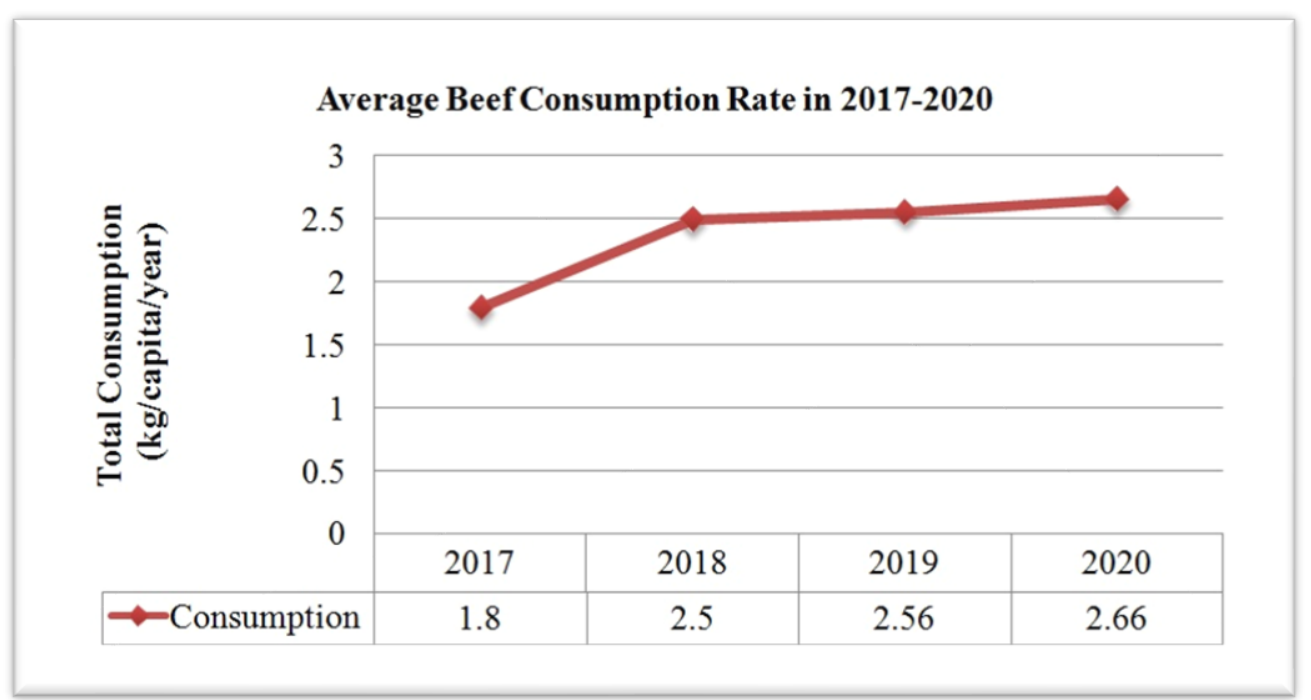

Figure 2. National beef cattle consumption of Indonesia Year 2017 - 2020 (Data is processed from Ministry of Agriculture, 2020).

The average level of meat consumption in Indonesia (Illustration 2) is lower compared to the average meat consumption in developed countries which reaches $6.4 \mathrm{~kg}$ (Ministry of Agriculture, 2020). This is caused by many factors including the lack of beef cattle population, high meat prices, business systems that are not business-oriented yet so the productivity is low, and production centers have not been well distributed to consumer areas thus efforts to increase population and to improve product quality and business systems are still needed to be carried out. (Ministry of Agriculture, 2020).

The development of livestock sub-sector is aimed at increasing the population and production of the livestock products (Statistic Indonesia, 2021c) of course with a good agribusiness system. However, in reality, the industrialization development of livestock, especially beef cattle are difficult to be implemented because of the current condition of beef cattle breeding scattered in various regions and not business-oriented yet (Ditjen $\mathrm{PKH}, 2018$ ). Other problems that are often experienced by smallholder breeders are the difficulty of obtaining additional capital, marketing, and the weakness of the institutional system, so that such conditions make the breeders' business stagnate, profits are relatively small and even tend to lose. Comprehensive, systematic, integrated, competitive, sustainable and decentralized strategies and policies under these conditions are needed to be implemented (Mayulu et al., 2010) including through a business approach towards a corporation. A corporate-based livestock area is a livestock area which developed with a strategy of empowering and cooperating farmers. The corporate approach can connect breeders with their livestock enterprises/business or develop their livestock enterprises/business. The corporate-based livestock area can be an idea as well as a strategy in solving problems related to the development of livestock business, so it is interesting to be discussed and studied more intensive.

\section{Materials and Methods}

The needs and demand for cattle meat continues to increase along with the increasing awareness of the importance of fulfilling nutrition (animal protein), increasing income per capita, increasing urbanization, and increasing spending on consumption of livestock products (Bekele et al., 2017; Traore et al., 2018; Ji-bin et al., 2021). Such conditions require the livestock sub-sector, especially large ruminants to increase productivity while still paying attention to the efficient uses of feed resources and environmental sustainability (Bekele et al., 2017; Cangio et al., 2021) as well as opening up great business opportunities for livestock producers (Yang, 2013). Beef cattle is the most popular large 
ruminant commodity that can produce meat (Hegde, 2019) so their development needs to be done. The current condition of beef cattle breeding in Indonesia is dominated by smallholder farmers (contributing to $90 \%$ of cattle production) with a very low scale of cattle ownership, which is an average of 2-3 heads, spreading throughout the region, and subsistence, making it difficult to develop towards industrialization (Ditjen PKH, 2018; Agus and Widi 2018). The population of beef cattle in Indonesia in 2020 reached to 17 466,8 thousand heads and meat production reached to 515628 tons (Statistic Indonsia, 2021e). Cattle production centers in Indonesia in 2016-2020 are concentrated in three provinces on the island of Java, namely: East Java (20.00\% contribution or an average meat production of 100,1 thousand tons), West Java (15.45\% contribution or meat production average of 77.97 thousand tons), and Central Java ( $12.43 \%$ contribution or an average meat production of 62.73 thousand tons). Such conditions can stimulate other regions to develop the beef cattle breeding businesses. East Kalimantan Province has the opportunity to become a center of beef cattle development considering the land availability and human resources.

The population and quality of cattle are factors that influence the dynamic of meat availability (Ismono et al., 2015). Cattle quality is reflected in the final body weight and carcass percentage. High body weight (according to the genetic potential) can be achieved through a good maintenance system and balanced nutritional needs (Ismono et al., 2015). The beef cattle rearing system is generally divided into three patterns, namely extensive, semi-intensive and intensive (Mayulu, 2021) with the goals of fattening business (feedlot) (Mayulu, 2015).

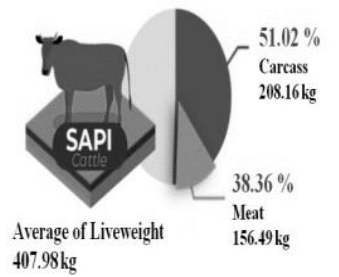

Year 2018

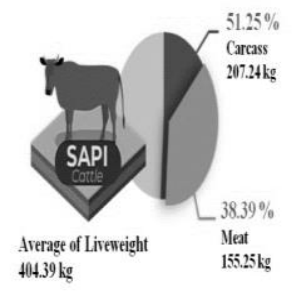

Year 2019

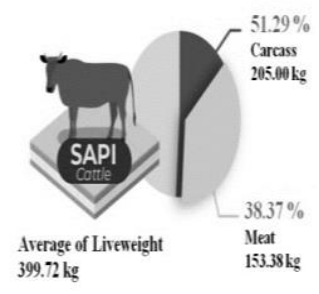

Year 2020

Figure 3. Average Body Weight, Carcass Production, and Meat of Beef Cattle (BPS, 2019a; Statistic Indonesia, 2020b; Statistic Indonesia, 2021c)

Table 1. Population, Meat Production and Carcass Production of Beef Cattle in East Kalimantan Province Year 2018-2020

\begin{tabular}{ccccc}
\hline \multirow{2}{*}{ Year } & Population (thousand heads) & \multicolumn{2}{c}{ Carcass Production } & $\begin{array}{c}\text { Meat Production } \\
\text { (Ton) }\end{array}$ \\
\cline { 3 - 5 } & & $\begin{array}{c}\text { Production } \\
\text { (Ton) }\end{array}$ & $\begin{array}{c}\text { Value } \\
\text { (million) }\end{array}$ & \\
\hline 2018 & $117.5^{*}$ & $3,196.82$ & $316,540.71$ & $7,944^{*}$ \\
2019 & $119.5^{* *}$ & $3,048.69$ & $252,883.51$ & $7,654^{* *}$ \\
2020 & $123.1^{* *}$ & $3,074.08$ & $317,203.4$ & $7,489^{* *}$ \\
\hline
\end{tabular}

Source: Statistic Indonesia, 2019; StatistiBPS, 2020; Statistic Indonesia, 2021b; *Statistic Indonesia, 2020; **Statistic Indonesia, 2021c. 
Table 2. Carcass Production of Beef Cattle in East Kalimantan Province Year 2018-2020 in Quarter Bases* $^{*}$

\begin{tabular}{ccccccc}
\hline & \multicolumn{7}{c}{ Year } \\
\cline { 2 - 7 } Quarter & \multicolumn{2}{c}{2018} & \multicolumn{2}{c}{2019} & \multicolumn{2}{c}{2020} \\
\cline { 2 - 7 } & $\begin{array}{c}\text { Production } \\
\text { (Ton) }\end{array}$ & $\begin{array}{c}\text { Value } \\
\text { (million) }\end{array}$ & $\begin{array}{c}\text { Production } \\
\text { (Ton) }\end{array}$ & $\begin{array}{c}\text { Value } \\
\text { (million) }\end{array}$ & $\begin{array}{c}\text { Production } \\
\text { (Ton) }\end{array}$ & $\begin{array}{c}\text { Value } \\
\text { (million) }\end{array}$ \\
\hline I (Januari-March) & 733.14 & $73,088.45$ & 667.68 & $42,687.01$ & 695.67 & $72,900.12$ \\
II (April-June) & 1024.71 & $96,755.98$ & 945.88 & $63,990.61$ & 826.65 & $86,535.62$ \\
III (Juli-September) & 721.17 & $73,131.79$ & 709.92 & $72,085.83$ & 723.17 & $73,038.71$ \\
IV (October- & 717.80 & $73,644.50$ & 725.22 & $74,120.07$ & 828.59 & $84,728.94$ \\
December) & & & & & & \\
\hline
\end{tabular}

Source: Statistic Indonesia, 2019; Statistic Indonesia, 2020; BPS, 2021a.

\section{Results}

\subsection{Livestock Area}

The increasing demand for animal food must be achieved with adequate management practices especially maintenance and feed management with taking into account the environmental conditions (Cangio et al., 2021). The development of the livestock industry is basically closely related to the availability of natural resources such as land (Lal, 2020; Daru and Mayulu, 2020). The availability of adequate natural resources, reared livestock commodities, and condition of the area or rearing area supports an efficient and sustainable livestock development policy (Mayulu and Daru, 2019). Land, feed, calf, labor are the main pillars that affect the productivity and sustainability of livestock business (Bekele et al., 2017). Land resources have a core role in the livestock sub-sector so that the determination of livestock areas shall guarantee the availability of land without having to compete with other sectors. The establishment of livestock areas will provide easiness in the management because the commodities are homogeneous and concentrated so it will be more efficient and more optimal in the resource utilization (holistic, commodity integration), more focus on the commodities, more efficient uses of budget (management scale effect) and more visible impacts (wide

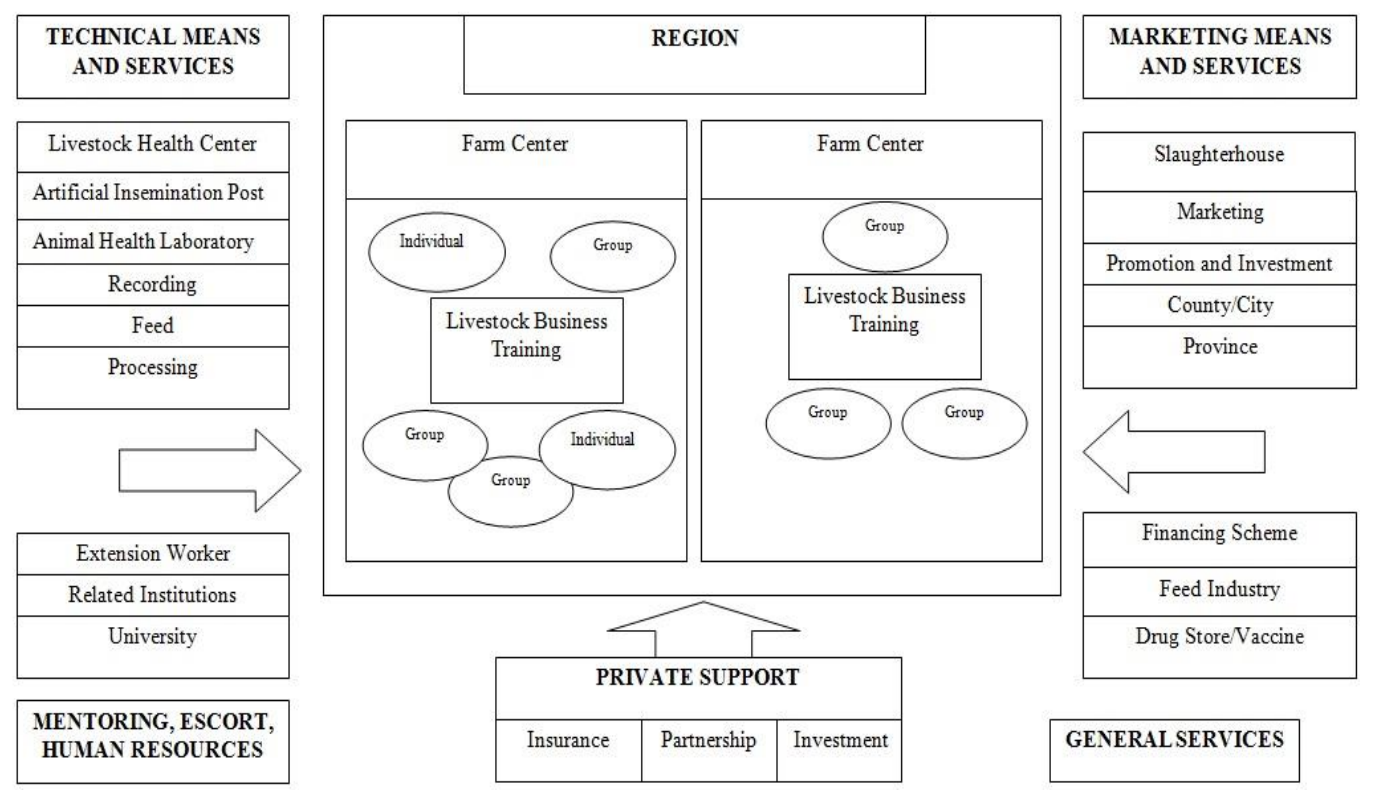

scale) (Secretary General of Agriculture, 2018).

Figure 4. Scheme of Livestock Area based on Regulation of the Minister of Agriculture of Indonesia Number: 18/ PERMENTAN/RC.040/4/2018. 
Based on its land resources, East Kalimantan Province is potential for livestock development areas, especially beef cattle, but not all districts have opportunities for livestock development areas. The area of East Kalimantan Province reaches 127 346,92 $\mathrm{km} 2$ and the area of land which is not cultivated is 815,249 hectares (Statistic Indonesia, 2018), so it is potential to promote livestock development. The development of priority commodity area is carried out based on the Decision of the Minister of Agriculture Number: 472/Kpts/RC.040/6/2018 about the Location of National Agricultural Areas which has determined the location of development-based commodity area in each region. In general, the livestock development area is a holistic area that provides guarantee for livestock productivity and economically feasible to establish livestock development center (Mayulu and Daru, 2019). The development of beef cattle commodities area as part of livestock development designated area is an effort to leverage the contribution of beef cattle on regional development through the increment of population, production and productivity (Susanti et al., 2014). These efforts are to promote the economic development in the region while maintaining the carrying capacity of available resources, thus a regional approach that can integrate regional potential and beef cattle commodities is needed. The availability of a specific area for the development of a commodity is expected to increase the efficiency of the commodity's production and distribution system. Because, principally, the regional approach is an effort to maximize the comparative advantage of a region (Susanti et al., 2014). The criteria for the development of beef cattle area set by the Directorate General of Livestock and Animal Health, Ministry of Agriculture are as follow:

1. The development area covers a unitary district/municipality administrative area in accordance with the Regional Spatial Planning (RSP) stipulated by the Regional Regulation in Regency/City Level;

2. The territorial unit refers to the spreading of potential natural resources that support the development of beef cattle agribusiness, and an effective control to livestock farmers who spread in those areas are not limited by administrative boundaries of villages and or sub-district government in one regency administrative area;

3. The regional agroecosystem promotes the development of beef cattle business, such as the availability of local natural resources, water resources, and not an endemic area for livestock's infectious diseases.

Areas that can be designated as beef cattle breeding area must meet these following requirements:

1. There is a group of breeders who are actively engaged in beef cattle breeding (as the nucleus in one area);

2. The beef cattle population owned by a group in the area is at least 1000 adult cattle in order to achieve the efficiency and economic scale;

3. Sources of forage and others additional feeds must be available. According to Mayulu and Daru (2019), livestock area should be supported by abundant availability of forage, plantation biomass, and agroindustrial waste that can promote the feed availability for livestock to achieve high productivity;

4. Facilities and infrastructures of beef cattle health services, artificial insemination and marketing must be available; and

5. Primary infrastructures facilities as supporting facilities such as electricity, clean water, fuel and road access must be available.

The accuracy in determining the area for livestock breeding is an important strategy that can be done to synergize the potential genetic advantages of livestock with existing regional resources, especially the availability of adequate local feed (Mayulu and Daru, 2019), considering that the geographic of an area affects health and feed management practices (Kihoro et al., 2021). The availability of abundant feed materials is the priority aspect that must be considered to decide the livestock rearing area. Silage of corn, rice straw and grass can be the main source of feed for fattening beef cattle (Cangio et al., 2021). 


\subsection{Farmers Corporation}

Livestock business in East Kalimantan Province is dominated by smallholder breeders (most of which are breeders' households) with small scale businesses. Smallholder's livestock is identical to business locations that are spread out in remote villages, lack of technical services and market connectivity, and experience low production and reduced income, so that in this situation, livestock businesses have no contribution to the economy. Smallholder livestock have lower business performance (daily weight gain ranges from 0.3-0.8 kg/head/day) compared to industrial-based commercial scale cattle fattening business performance (daily weight gain reaches $1-1.4 \mathrm{~kg} / \mathrm{head} /$ day) (Ismono et al., 2015). The government has taken optimization efforts of beef cattle production, including strengthening beef cattle farming financing (Ministry of Agriculture, 2020)

Institution, in principle, is an effort to transform the livestock sector. However, institution at the breeder's level and at the coordinating level are actually an obstacle to the development of livestock businesses, apart from capital (International Livestock Research Institute, 2019). There are still many breeders institutional condition that do not meet expectations, this is due to: 1 ) not yet oriented to productive businesses; 2) access to financing/banking sources and market networks is not yet optimal; 3 ) has not been able to connect with sources of information, technology, and market leading to less competitive with other business actors; and 4) has not been able to serve the needs of agribusiness development for its members (Ditjen PKH, 2015). This is caused by the lack of socialization and readiness of breeders to institutional patterns, thus strengthening aspects of business supports in terms of technology and institution to support business development is very necessary (Susanti et al., 2014). The strengthening of breeder institution is also expected to be able to stimulate breeders to be more independent and competitive (Ditjen PKH, 2015). The breeder institution is defined as an institution developed from, by, and for breeders in order to strengthen cooperation in struggling their interest in form of groups and groups union (Ditjen PKH, 2015).

Assistance and empowerment of breeders in the development of innovation and technology, supporting facilities and infrastructure (machines), processing of animal feed and manure, as well as determining production targets related to marketing of products can be carried out to strengthen breeder institutions. Such a strategy can be implemented through a corporation approach, so it is expected that it will form a business-oriented livestock agribusiness and ultimately be able to improve the bargaining position of breeders and the products produced by breeders (Mayulu and Daru, 2019; Hegde, 2019). Saving and insurance owned by breeders in institutional program can strengthen businesses (Camara et al., 2019). The breeder corporation is a breeder's economic institution with a legal entity in the form of a cooperative or other legal entity with most of the capital ownership owned by the breeder. The concept of breeder corporation will provide new strengths such as human resources, capital, and banking that are included in business development, so that the opportunities for success and progress of the breeder's business are more open. Important strategies that can improve the added value and competitiveness of livestock include: improving human resource capacity of breeders, breeder institutions (cooperative), development of complementary sectors (agro-industry, provision of credit, application of appropriate technology), improvement of logistic system, and provision of information and development of innovation and technology as well as market network expansion for breeders (Ditjen PKH, 2020). 


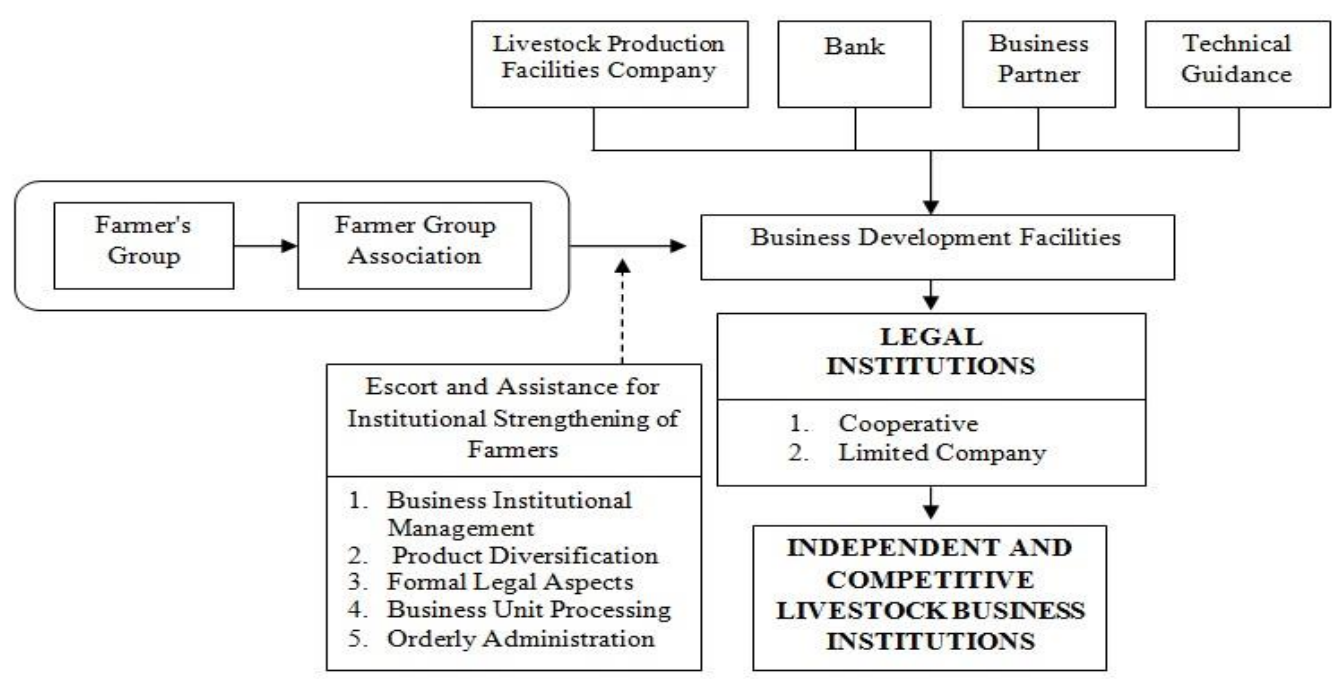

Figure 5. Breeder Institutional Strengthening Scheme (Ditjen PKH, 2015).

\subsection{Corporate Beef Cattle Development Area}

The development of beef cattle agribusiness area is the development of the entire agribusiness subsystem simultaneously and integrated from upstream to downstream as a business institution (Ditjen PKH, 2018). The strengthening of breeder institution is carried out through coordination and assistance in efforts to develop livestock business partnerships and develop corporate-based livestock areas in 2020 (Ditjen PKH, 2020). The development of a corporate-based beef cattle breeding area is an approach which needs to be taken to achieve a business and industrial-beef cattle breeding. This approach is in synergy with the vision of the Directorate General of Livestock and Animal Health, namely: "The realization of competitive and sustainable Indonesian livestock in realizing advanced, independent and modern Indonesian agriculture" (Ditjen PKH, 2020). The pattern of the development of corporate-based beef cattle breeding areas is in accordance with Law Number: 19 Year 2013 concerning Protection and Empowerment of Farmers and based on Regulation of the Minister of Agriculture Number: 48 Year 2018 concerning Guidelines for the Development of Corporation-Based Agricultural Areas (Ditjen PKH, 2018). Areas which have been designated as corporate-based beef cattle breeding development areas in Indonesia include 1) Beef Cattle Area in Tuban, East Java; 2) Beef Cattle Area in Subang, West Java; 3) Beef Cattle Area in East Lombok NTB, 4) Beef Cattle Area in South Lampung; 5) Beef Cattle Area in North Bengkulu, Bengkulu; 6) Ngada Regency; 7) Gowa Regency; 8) Central Lombok Regency; and 9) Probolinggo Regency (Ditjen PKH, 2020) do not stop the possibility in East Kalimantan Province.

Livestock business development must be carried out collectively, integrated and holistically, because livestock is an interconnected value chain from production inputs (upstream subsystem), production process (on farm), post-harvest handling/downstream (off farm) to consumers (marketing) (Oosting et al., 2014) and the subsystem of supporting services (such as government policies, financial and financial institutions, insurance, extension and information services, transportation, research and development (Ismono et al., 2015). Upstream agribusiness subsystem (production of calf, feed, livestock production facilities) and on-farm beef cattle breeding are generally located in rural areas, while downstream agribusiness subsystems (post-harvest handling, processing, marketing of products) are located in urban areas and these subsystems are interconnected. Animal husbandry needs to be developed in an efficient business scale in one corporate area so that all of the factor components can be simultaneously done in an efficient way, effective and integrated to produce various products that can improve the added value and competitiveness (Ditjen PKH, 2018). The development of corporatebased beef cattle breeding areas is carried out in an integrated and sustainable manner 
starting from the upstream to downstream subsystems in a livestock business system while still paying attention to economic aspects, socio-cultural aspects, technical aspects (science and technology), and ecological or environmental aspects. Beef cattle breeding areas must be supported by the availability of pasture land and/or land to plant forage and can be developed with an integration pattern between plantation crops and beef cattle, food crops with beef cattle and or horticulture with beef cattle (Mayulu et al., 2010; Oosting et al., 2014). The development of a corporate-based beef cattle breeding area aims to: 1) increase the competitiveness and added value of the region and beef cattle commodities in supporting national sustainable food security; 2) strengthen the livestock business system in one area management in holistic manner; and 3) strengthening breeder institution in accessing information, technology, public facilities and infrastructure, capital, processing and marketing. The targets for developing a corporate-based beef cattle breeding area are:

1. Increasing production, productivity, added value and competitiveness of beef cattle;

2. Optimal availability of animal husbandry facilities and infrastructure supports in the beef cattle breeding areas;

3. Application of innovative technology in accordance with the specific location in the breeding development area of beef cattle;

4. Improving breeders' knowledge, skill, and entrepreneurship abilities in managing beef cattle breeding economic institutions; and

5. The functioning of an integrated, effective, efficient and sustainable beef cattle breeding business system.

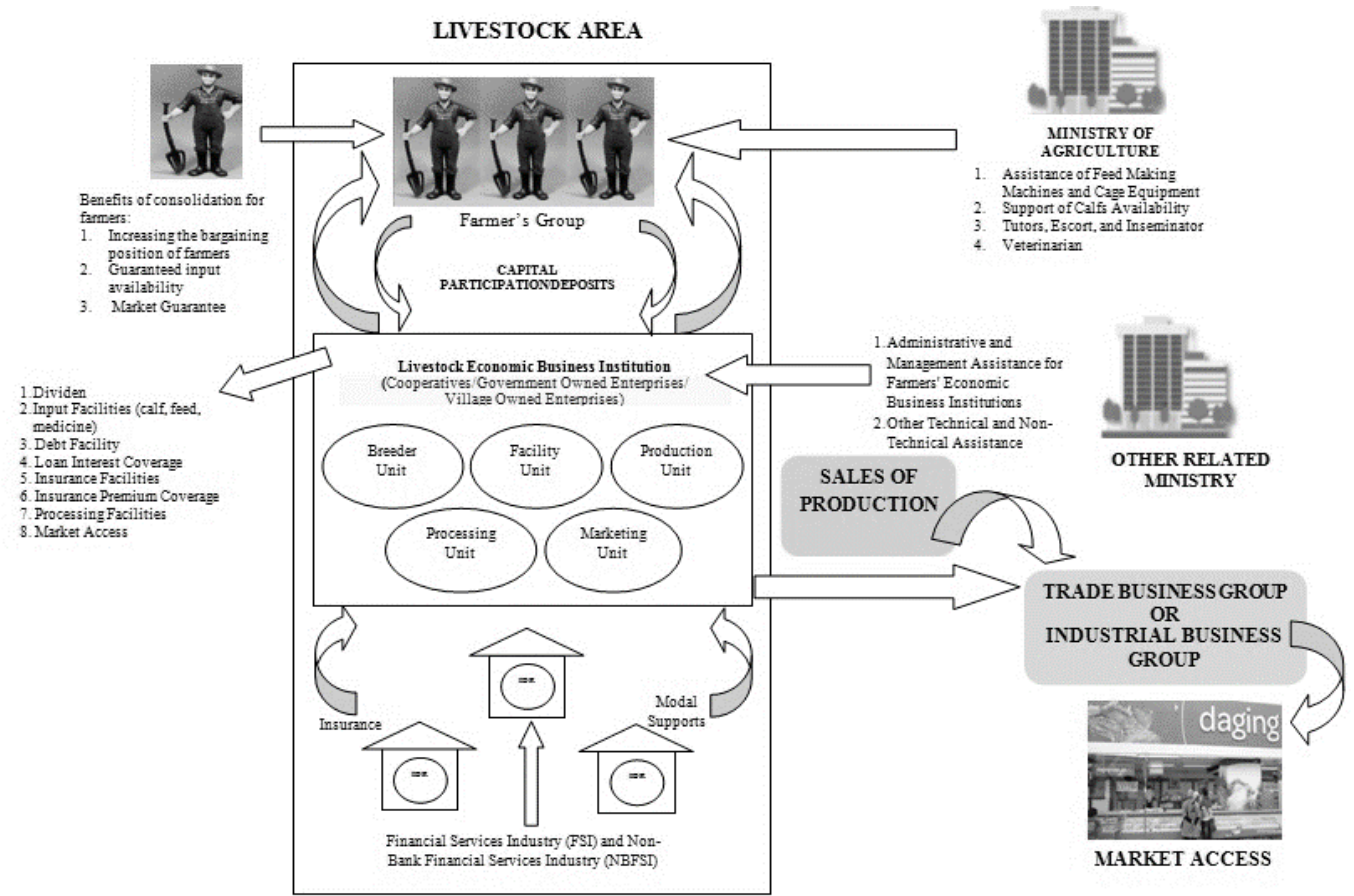

Figure 6. Corporate-Based Livestock

The development of a corporate-based livestock area is not only focus on increasing the production, productivity and quality of beef cattle, but also involves many important aspects such as human resources (HR), the involvement of the government, private sector, academics, banks and cooperatives.

The capacity, quality and integrity of human resources as the actors in livestock business will determine the performance of livestock development (Ismono et al., 2015). Groups of breeders, traders, small and medium entrepreneur role as the main actors in the implementation of beef cattle breeding area (Ditjen PKH, 2018). Therefore, it is expected to stimulate the combination of strategic activities in adequate economic level, both in on farm and off farm towards the industrial level integrated in an agribusiness 
system. Breeders often experience limit access to input, information and services, thus needs to be fully empowered in terms of input technology, financial/capital support, information and marketing (Agus and Widi, 2018).

The human resources capacity of breeders can be improved by training, counseling, field assistance through empowerment programs. Empowerment of breeder groups is a process, method, program, institution, and movement that involves the community as a basis for being educated and trained in solving problems in a democratic manner. Strengthening the economic institutions of beef cattle breeders (breeder groups and farmers groups union) in the area into business institutions (corporations) is an effort which developed in empowering breeders (Ditjen PKH, 2018). A sense of ownership, participation, and creative development must be encouraged to breeders as an effective approach in understanding and utilizing the corporate-based beef cattle breeding area development program in a sustainable manner. Empowerment programs can be a means of interaction between breeders and other main actors so it impacts on the sense of mutual need, complementing, strengthening each other, and enhancing each other. This attitude is expected as a mean of improving knowledge and ability in managing beef cattle system and businesses professionally (Ditjen PKH, 2018). Strengthening livestock institution is very strategic in improving the performance and competitiveness of the livestock business. Additionally, through breeder groups, collective action can be taken to realize the synergy and to achieve more viable business scale (Ismono et al., 2015).

\section{Discussion}

Breeder corporation will facilitate collaboration between breeders, large companies, small and medium enterprises, home industries and other supporting institutions in the production, processing, trade and integration with wider market (Ditjen PKH, 2018). The breeder group is the human resource that has the potential to determine the success of the development of a corporate-based beef cattle farming area, in addition to the number of cattle owned and other infrastructure (Ditjen PKH, 2018). The activities of corporate-based beef cattle breeders in on farm subsystem have a great opportunity to be optimized and be more efficient, both in terms of productivity and waste management. Adoption of appropriate technology in the livestock business is highly recommended for business efficiency, but must be balanced with good markets and institutions (Oosting et al., 2014). Optimization and efficiency can be done by utilizing agricultural by-products as feed ingredients (Leinonen, 2019; Mayulu et al., 2010). Adult cattle are able to produce $25.5-30 \mathrm{~kg}$ of feces per day, so it must be utilized. Utilization of cattle feces can be processed into fertilizer and renewable energy such as biogas and biochar (Itoh et al., 2019). The use of organic fertilizers based on urine and livestock feces can fertilize the soil (Wang et al., 2020), thus it can reduce the uses of pesticides, especially in agriculture. Processing feces into fertilizer, biogas and biochar in addition to support sustainable livestock breeding also provides benefits to breeders because it will impact on the breeding efficiency.

The government plays a core role in formulating and making policies and regulations. Policies and regulations which made by the government greatly determine the ability of economic competitiveness, thus regulations must be able to encourage the growth of a competitive livestock business (Ismono et al., 2015). Government also has a role in promoting a more conducive business climate in order to attract the private sector to be involved in the development of livestock business (Mayulu and Daru, 2019) and make special policies and regulations to protect breeders from middlemen as an effort to increase the growth of beef cattle industry (Agus and Widi, 2018). Government policies and regulations which cover activities from upstream to downstream are very needed to encourage the establishment of production input sub-system and process efficiency in production, post-harvest, processing, and marketing (Ismono et al., 2015; Agus and Widi, 2018). The ministries which involve in the livestock corporation are ministry of economy, ministry of agriculture and ministry of cooperatives. 
The development of corporate-based livestock needs to be supported by related subsectors, both from government and private sector. Private sector involvement in livestock business development is very important and one of its from is through partnerships (International Livestock Research Institute, 2019). Partnership cooperation should be encouraged to build synergies between nucleus-plasma companies in corporate-based beef cattle agribusiness including in terms of procurement of production facilities, breeding, post-harvest, quality improvement and marketing (Ismono et al., 2015). Partnerships with millennial breeders in the era of modern livestock and technological advances are highly expected to be carried out on corporate-based beef cattle breeding because technology and information are important to support the success of livestock businesses now and in the future. Advanced digitalization technology can help modern breeders optimize the contribution of livestock to the economy, ease the work of breeders and is expected to be a solution to the problems that are often experienced by breeders, especially in the marketing aspect (Neethirajan and Kemp, 2021).

Intensification of livestock business is not only carried out in terms of production but also in terms of financing (Oosting et al., 2014). Financing for livestock business is a strategic aspect that becomes a priority in livestock development and is currently still a big problem that is often faced by farmers (Ismono et al., 2015). The support of financing/capital sources is very much needed in realizing a corporate-based beef cattle breeding area as a source of economic growth. Sources of financing/capital include:

1. Government funds (through the State Budget) are designated to provide technical infrastructures needed in the development of corporate-based beef cattle breeding areas, while regional government state budget (Provincial/District/City level) are used to complete basic public infrastructures, human resource capacity development, institutional development and to promote the development of beef cattle business in the region;

2. Financing/capital from financial institutions/banks such as micro credit, and other financing that can be accessed by breeder/breeder groups within the corporate area of beef cattle breeding; and

3. Financing that is provided by private sector/investor through Corporate Social Responsibility (CSR) in the form of business partnership and capital participation for community (can be accessed after the business performance of the breeder groups is very prospective) (Ditjen PKH, 2018).

Capital support for breeders or breeder groups is designed with a form of direct link between bank and Area Management Unit (AMU) as the micro entrepreneur or saving and loan group sourced from the nearest commercial bank, regional develompment banks (RDB), and rural banks who are willing and able to be accessed by micro entrepreneur group/saving and loan group as the executing bank. The role of extension from Supervisory Board, Government, Company, Non-Government Organization (NGO) and or higher education are important to encourage and to assist the breeders in the development area through UMK so that it can fulfill the credit requirement criteria for direct distribution from bank (Ditjen PKH, 2018). Active participation from financial institutions can be carried out through the development of credit scheme for livestock business activities. This credit scheme needs to have interest subsidies, simple administration procedure, and short processing time. The subsidy scheme is expected to be used to subsidy the bank interest and in the aspect of financing is needed to make special credit insurance for livestock (Ismono et al., 2015). The Ministry of Agriculture in year 2020 sets target of micro credit distribution by IDR 9.01 trillion and the realization was IDR 10.57 trillion or achieved the performance of $117.30 \%$ from target, while the financing from Environmental Development Partnership Program (EDPP) of StateOwned Company (BUMN) was IDR5.96 billion. In the period of 2016-2020, insurance assistance for cattle reached to 120.000 heads/year and the insurance fee was $2 \%$ from the insurance value. The insured value was $2 \%$ x IDR10,000,000 = IDR 200,000/head/year. 
Government gives insurance fee donation from APBN as much as 80\% or IDR160.000 and the rest $(20 \%$ or IDR40,000) is paid by breeders (Ditjen PKH, 2020).

\section{Conclusions}

The development of beef cattle agribusiness area is the development of the entire agribusiness subsystem simultaneously and integrated from upstream to downstream as a business institution. The development of a corporate-based beef cattle breeding area is an approach which taken toward industrial and business-oriented beef cattle breeding. The concept of breeder corporation will create new strengths such as strengths in human resources, capital, and banking in business development, which can more open the opportunities for the success and growth of the breeder's business. The development of a corporate-based beef cattle breeding area provides opportunities, including: 1) improving the competitiveness and added value of the region and beef cattle commodities in order to support national sustainable food security; 2) strengthening the livestock business system in one area management in a holistic manner; and 3) strengthening breeders institutions in accessing information, technology, public facilities and infrastructure, capital, processing and marketing, so that the concept is expected to be able to solve problems which oftenly faced by breeders.

\section{References}

1. Agus, A and T. S. M. Widi. 2018. Current situation and prospect of beef cattle production in Indonesia-A review. AsianAustralas J Anim Sci., 31: 1-8. https://doi.org/10.5713/ajas.18.0233

2. Bekele, M., A. Mengistu, and B. Tamir. 2017. Livestock and feed water productivity in the mixed crop-livestock system. Animal, 11 (10): 1852-1860. https://doi.org/10.1017/S1751731117000416

3. Camara, Y., N. Moula, F. Sow, M. M. Sissokho and N. A. Moussiaux. 2019. Analysing innovations among cattle smallholders to evaluate the adequacy of breeding programs. Animal, 13 (2): 417-426. https://doi.org/10.1017/S1751731118001544

4. Cammarata, M., G. Timpanaro and A. Scuderi. 2021. Assessing sustainability of organic livestock farmingin sicily: a case study using the FAO SAFA framewor. Agriculture, 11: 1-20. http://doi.org/10.3390/agriculture11030274.

5. Congio, G, F, S, C., A. Bannink, O. L. M. Mogoll'on, Latin America Methane Project Collaborators, and A. N. Hristov. 2021. Enteric methane mitigation strategies for ruminant livestock systems in the Latin America and Caribbean region: A metaanalysis. Journal of Cleaner Production, 312: 1-13. http://doi.org/10.1016/j.jclepro.2021.127693.

6. Daru, T.P and Mayulu, H. 2020. Optimization of land resources through forages development. European Journal of Molecular \& Clinical Medicine, 7 (7): 5000-5013.

7. Directorate General of Livestock and Animal Health (Ditjen PKH). 2015. Guidelines on the implementation of breeders institutional strengthening. Ministry of Agriculture.

8. Directorate General of Livestock and Animal Health (Ditjen PKH). 2018. Operational instruction on the development of corporate-beef cattle area. Ministry of Agriculture.

9. Directorate General of Livestock and Animal Health (Ditjen PKH). 2020. Working report 2020. Ministry of Agriculture.

10. Elly, F. H., A. H. S. Salendu, C. L. Kaunang, Indriana, R. Pomolango, and Syarifuddin. 2018. Forage introduction to support development of cattle in Sangkub District. International Journal of Environment, Agriculture and Biotechnology (IJEAB), 3 (5): 1718-1720. http://dx.doi.org/10.22161/ijeab/3.5.19.

11. Hegde, N. G. 2019. Livestock development for sustainable livelihood of small farmers. Asian Journal of Research in Animal and Veterinary Sciences, 3 (2): 1-17.

12. Ismono, R. H., Erwanto, D. A. H. Lestari, W. D. Sayekti, D. Haryono, K. Adhianto, H. Nasution, and H. E. Riyadi. 2015. Tematic analys of ST2013 in the beef cattle household agribusiness sub-sector and self-sufficiency target. Statistics Indonesia.

13. International Livestock Research Institute. 2019. Option for the livestock sector in developing and Emerging Economies to 2030 and Beyond Commited to improving the state of the world, World Economic Forum, Switzerland. pp.127. [Dwonload August 2021]. Available In: http://www3.weforum.org/docs/White_Paper_Livestock_Emerging\%20Economies.pdf

14. Itoh, T., K. Iwabuchi, N. Maemoku, I, Sasaki, and K. Taniguro. 2019. A new torrefaction system employing spontaneous self-heating of livestock manure under pressure. Waste Management, 85: 66-72. http://doi.org/10.1016/j.wasman.2018.12.018.

15. Ji-bin, Z., Z. Jia, L. Jia-Hui, J. K. Tomerlin, X. X. Peng, K. U. Rehman, C. M. Min, Z. L. Yu, and Y. Z. Niu. 2021. Black soldier fly: A new vista for livestock and poultry manure management. Journal of Integrative Agriculture, 20(5): 1167-1179. Doi: 10.1016/S2095-3119(20)63423-2. 
16. Kihoro, E. M., G. C. Schoneveld, and T.A. Crane. 2021. Pathways toward inclusive low-emission dairy development in Tanzania: Producer heterogeneity and implications for intervention design. Agricultural Systems, 190: 1-16. http://doi.org/10.1016/j.agsy.2021.103073.

17. Lal, R. 2020. Integrating animal husbandry with crops and trees. Frontiers in Sustainable Food Systems, 4 (113): 1-12. https://doi.org/10.3389/fsufs.2020.00113

18. Leinonen, I. 2019. Achieving environmentally sustainable livestock production. Sustainability,11 (246): 1-5. https://doi.org/10.3390/su11010246

19.

20. Mayulu, H., Sunarso, C. I. Sutrisno, and Sumarsono. 2010. Beef cattle development policy in Indonesia. Journal of Agricultural Research and Development, 29 (1): 34-41.

21. Mayulu, H and T. P. Daru. 2019. Region based of animal husbandry development policy: a case study in East Kalimantan. Journal of Tropical AgriFood, 1 (2): 49-60. http://dx.doi.org/10.35941/jtaf.1.2.2019.2583.49-60.

22. Mayulu, H. 2015. Feed and fattening efficiency of beef cattle. Unnes Pres. Semarang.

23. Mayulu, H. 2021. Beef cattle and its business management. RajaGrafindo Persada. Depok.

24. Ministry of Agriculture. 2020. Beef Cattle Outlook. Center of Agricultural Data and Information, Secretariate GeneralMinistry of Agriculture. http://epublikasi.setjen.pertanian.go.id/

25. National Development Planning Agency (Bappenas). 2021. President Regulation of the Republic of Indonesia Number: 122 Year 2021 on the update of government working plan year 2020. Ministry of National Development Planning/National Development Planning Agency (Bappenas) 2020.

26. National Bank for Agriculture and Rural Development (NABARD). 2018. Sectoral paper on animal husbandry. Farm Sector Policy Department NABARD Head Office, Mumbai.

27. Neethirajan, S and B. Kemp. 2021. Digital livestock farming. Sensing and Bio-Sensing Research, 32 : 1-12. https://doi.org/10.1016/j.sbsr.2021.100408.

28. Oosting, S. J., H. M. J. Udo and T. C. Viets. 2014. Development of livestock production in the tropics: farm and farmers' perspectives. Animal, 8 (8): 1238-1248. https://doi.org/10.1017/S1751731114000548.

29. Secretariate General of the Ministry of Agriculture (Setjen Pertanian). 2018. Policy on the development of agricultural area. Presented on the Socializatin of Map and Master Plan and Action Plan Workshop in Grand Mega Resort and Spa, Bali Date 13 - 15 February 2018.

30. Statistics Indonesia (BPS)a. 2019. Statistics of livestocks slaughtered 2020. Statistics Indonesia.

31. Statistics Indonesia (BPS)b. 2020. Statistics of livestocks slaughtered 2020. Statistics Indonesia.

32. Statistics Indonesia (BPS)c. 2021. Statistics of livestocks slaughtered 2020. Statistics Indonesia.

33. Statistics Indonesia (BPS)d. 2021. Statistics of Indonesia in number 2020. Statistics Indonesia.

34. Statistics Indonesia (BPS)e. 2021. Statistics of Indonesia in number 2021. Statistics Indonesia.

35. Statistics Indonesia (BPS)f. 2018. Statistics of East Kalimantan Province in number 2018. Statistics Indonesia.

36. Susanti, Y., D. S. Priyarsono, and S. Mulatsih. 2014. The development of beef cattle breeding to improve the economic of Central Java: a regional planning approach. Journal of Indonesia Agribusiness, 2(2): 177-190.

37. Traoré, S.G., G. Fokou, A. P. N. Ndour, B. Yougbare, P. Koné, S. Alonso, K. Roesel, S. N. Bakou, D. Dao, D. Grace, and B. Bonfoh. 2018. Assessing knowledge, beliefs and practices related to the consumption of sheep and goat meat in Senegal. Global Food Security, 19: 64-70. https://doi.org/10.1016/j.gfs.2018.10.001.

38. Yang, H. 2013. Livestock development in China: animal production, consumption and genetic resources. J. Anim. Breed. Genet, 130: 249-251. https://doi.org/10.1111/jbg.12045

39. Wang, Y., Y. Sun, S. Chang, Z. Wang, H. Fu, W. Zhang, F. Hou. 2020. Restoration Practices affect alpine meadow ecosystem coupling and functions. Rangeland Ecology \& Management, 73: 441-451. http://doi.org/10.1016/j.rama.2020.01.004. 